\title{
Speaking for Nature: Hobbes, Latour, and the Democratic Representation of Nonhumans
}

\author{
Mark B. Brown \\ Department of Government, California State University, Sacramento, USA / mark.brown@csus.edu
}

\begin{abstract}
Environmental theorists have often considered how best to represent nature's interests. This essay develops an approach to the democratic representation of nonhuman nature by examining the relation between Bruno Latour's account of representation and that of Thomas Hobbes. Both Hobbes and Latour develop a constructivist theory of representation as an ongoing process that partly constitutes what it represents. In this respect, Latour's account complements the constructivist turn in recent democratic theory, and it suggests a promising avenue for representing nonhumans. However, Latour also follows Hobbes in viewing representation as a matter of unifying and replacing the represented. This aspect of Latour's approach obscures certain key features of representative democracy in pluralist societies. The last part of the essay takes up an aspect of Hobbes's theory neglected by Latour, the notion of representation by fiction, which suggests a way of representing nonhumans that offers more support for representative democracy than other approaches.
\end{abstract}

Keywords: Latour, Hobbes, representation

\section{Introduction}

Environmental theorists have frequently asked who "speaks for nature" or "represents nature's interests" (Dobson, 1996, 2010; Eckersley, 2000, 2004, 2011; Goodin, 1996; O'Neill, 2001, 2006). This essay develops an approach to the democratic representation of nonhuman nature by examining the relation between Bruno Latour's account of representation and that of Thomas Hobbes. One of Latour's most significant early essays draws directly on Hobbes's political theory (Callon and Latour, 1981), and Latour presents his influential argument that "we have never been modern" in terms of the controversy between Hobbes and Robert Boyle (Latour, 1993). Latour has also repeatedly referenced Carl Schmitt's Hobbesian rejection of transcendental foundations for politics (Latour, 2002: 26, 38; Latour, 2004: 278n64; Harman, 2014: 141-147). And as I show later in this essay, Latour discusses representation with terminology that directly echoes Hobbes. It is thus not surprising that Graham Harman (2014) describes Latour as "a liberally minded Hobbesian who adds inanimate entities to the political sphere" (Harman, 2014: 5). Harman even reports that he once "asked Latour about his earliest enthusiasm in political philosophy, and without hesitation he answered: 'Hobbes'"' (Harman, 2014: 5). Harman goes on to argue that Latour has an ambivalent relation to the Hobbesian tradition, but "his tension with Hobbes is the engine of his entire 
political philosophy" (Harman, 2014: 19). ${ }^{1}$ Harman sees Hobbes's influence in Latour's constructivism and in the "Power Politics" of Latour's early studies on scientific practice as strategic alliance building (Harman, 2014: 3-4, 29-31, 180). Harman does not address Hobbes's theory of representation and its central role in Latour's political theory.

Both Hobbes and Latour develop a constructivist theory of representation as a process that transforms what it represents. They both argue that the represented are at least partly constituted by the process of representation itself. In Latour's terminology, representation involves mediation and translation between various spokespersons and the hybrid associations of humans and nonhumans that they represent (Latour, 2004). In these respects, Latour's account complements the constructivist turn in recent work on representation by political theorists (Disch, 2015). A constructivist approach to representing nonhuman nature is more conductive to pluralist democracy than approaches based on nonnegotiable moral or scientific claims. However, Latour's account of representation remains inadequate for the democratic representation of nonhumans, due in part to his apparent reliance on additional aspects of Hobbes's theory. Like Hobbes, Latour portrays representation as a matter of uniting and replacing disparate individuals by a single authoritative spokesperson (Latour, 2003: 150; Latour, 2013: 341). Representatives thus effectively act in place of their constituents, leaving little room for ordinary citizens in the process of representation itself. To be sure, Hobbes rejects democracy and Latour endorses it, but they both assume an opposition between citizen participation and political representation. Latour does not advocate direct democracy, but he implicitly adopts its logic of identity, which says that representatives ideally should do what their constituents would have done. In this respect, and despite his well known constructivism, Latour remains indebted to a correspondence model of representation as a mirror of reality. Echoing Hobbes, Latour portrays representation as a matter of constructing a unified people by authorizing representatives who then, ideally, substitute for and thus directly correspond to the people's collective will. Of course, Latour argues that such correspondence is inevitably imperfect, and so representation is always disappointing. But he offers no other view of representation that might prove less disappointing. Latour's approach thus provides little support for efforts to understand the diverse ecology of representative claims that characterize democratic politics today.

I develop the beginnings of a more promising approach in the last part of the essay, by taking up an aspect of Hobbes's theory neglected by Latour: the notion of "representation by fiction" (Hobbes, 1991: 111-114). Hobbes argues that if a person or thing cannot authorize its own representative, a representative can be authorized by someone else. The person or thing is then represented "by fiction." Nonhumans cannot authorize their own representatives, and Hobbes's discussion of "representation by fiction" suggests a way of representing nonhuman nature that, despite Hobbes's antipathy toward democracy, is actually more conducive to representative democracy than other approaches.

\section{Nature's epistemic trustees}

Most accounts of how to represent nonhuman nature rely on humans adopting the role of nature's trustees, and the authority of such trustees generally rests on scientific research, moral intuition, empathic understanding, indigenous culture, or some other form of knowledge broadly defined (Carbone, 2004; Eckersley, 2004: 121-126; Goodin, 1996; O'Neill, 2001: 494-495; Schlosberg, 2007: 193-199). ${ }^{2}$ According to Goodin (1996: 844), for example, humans can best represent nonhumans by discerning and internalizing their interests and then acting with those interests in mind. Dobson (1996: 137) proposes that nonhumans could be represented by human "proxy-representatives," who would be elected by a designated "sustainability lobby" comprised of professionals charged with determining the conditions under which the animals, species, or habitats in question will survive and flourish. Dryzek (2000: 149) recommends that we respectfully "listen to signals emanating from the natural world" and then rely on those signals to assess nature's interests. Eckersley (2011: 237) sees nature's representa- 
tives as "self-appointed guardians or trustees of nature who want the community at large to share in the duty of care they feel towards their ward." These accounts often assert an analogy between the political inclusion of nonhumans and the inclusion of women, ethnic minorities, and other previously excluded social groups (Dobson, 2010: 753; Eckersley, 2011: 241, 244-49; Latour, 2004: 69). These accounts also generally acknowledge that nonhumans cannot directly authorize their representatives or hold them accountable. And as O'Neill (2001) points out, humans who represent nonhumans probably cannot claim authority based on perceived resemblance or likeness between themselves and those they represent. So most accounts argue that science, morality, or other epistemic resources can be used to discern the interests of nonhuman nature and justify claims to represent it (Eckersley, 2011: 252; O'Neill, 2001: 496). From this perspective, the authority of nature's representatives depends primarily on their claim to know something about nature.

These efforts to expand standard conceptions of political representation to include nonhumans clearly speak to an urgent moral and political need. They rightly note that existing institutions of electoral democracy often create incentives for public officials to favor short-term concerns and powerful interests over the needs of nonhuman nature, future generations, and people in other countries. They also vividly capture the idea that nonhuman nature should not be reduced to a material resource for human exploitation. They rightly reject the modernist dichotomy between humans as endowed with free will and agency, on the one hand, and nonhuman nature as inert matter, on the other.

Unfortunately, most accounts of representing nonhuman nature adopt a correspondence view of representation that undermines their democratic aims. As Michael Saward (2006; 2010: 111-120) argues, most such efforts view representation as the unidirectional transmission of information from nonhuman nature to its representatives. From this perspective, representation involves first discerning and then promoting nature's interests in a manner that is either morally authentic or scientifically objective. These authors do not portray representation as a matter of dialog or interaction between representatives and constituents. Instead they tend to cast the representative as a passive recipient of input transmitted directly from the represented. The implicit ideal is Rosseauean direct democracy, which strives for an identity of citizens and their government. This approach is driven by an ethic of immediacy that views representation as a mirror of reality (Brown, 2009: 70-78; Saward, 2006: 191).

With regard to epistemology, the correspondence view of representation has long been persuasively challenged by constructivist approaches in pragmatist and feminist philosophy, science and technology studies, and related fields (Jasanoff et al., 1995). From a constructivist perspective, representations of nonhuman nature-whether in science, art, morality, or politics - are always partly constituted by cultural values, social interests, and political decisions.

In terms of its political implications, the correspondence approach tends to lead in one of two directions. Because representatives inevitably fail to perfectly mirror the represented, a correspondence view of representation may generate intense skepticism toward representative institutions and the concept of representation itself. Such skepticism appears in Rousseau, advocates of direct democracy, and various forms of populism. Alternatively, the correspondence approach may offer support for elitist theories of representative government, which assume that governmental decisions should correspond to the preexisting reality of an objective public interest discerned by virtuous experts. In either case, deliberation and judgment is reserved for a governing elite, and ordinary citizens are asked only to express their unmediated will through voting, protest, or public acclamation (Brown, 2009).

Most importantly, when nature's trustees are understood in terms of a correspondence view of representation, they are likely to become either moral or scientific technocrats who attempt to shut down democratic debate with claims to speak for nature's objective interests. Nonhumans themselves cannot object to being represented by technocratic trustees. But when such trustees make non-negotiable demands that leave little room for democratic debate and compromise, they are likely to be rejected by other humans. 
Indeed, technocracy is not the actual problem, because when major interests are at stake, such as with regard to climate change, claims to speak for nature are inevitably contested. Nature's trustees then easily become just one more interest group among many. They compete among themselves and against other representatives who speak for other interests. Conflicts become entrenched and irresolvable, because for those who claim to represent objective interests, compromise seems like failure (Sarewitz, 2004).

In light of such difficulties with the idea of representing nature, some have argued that the entire project is misplaced. Ted Nordhaus and Michael Shellenberger (2007: 39, 50) reject the notion that environmentalism depends on "representing nature's interests," because they think it reinforces a romantic view of nature as pure and pristine, requiring protection from human intrusion. They argue that the question of who speaks for nature is itself "profoundly authoritarian," because it allows those with scientific expertise, local knowledge, or some other epistemic resource to dominate public decision making (Nordhaus and Shellenberger, 2007: 102). Similarly, Kerry Whiteside (2013: 354) argues that nonhuman interests cannot be represented in a democratic manner, because nonhumans cannot hold their representatives accountable. Whiteside (2012: 7) concludes that "representing nature" should be understood solely as a matter of "making representations" of nature, in the sense of portrayals that "stand for" natural phenomena, rather than as "acting for" nonhuman interests. More generally, Whiteside argues that in wealthy consumer societies, the short-term interests of humans are already represented far too well, so more representation is not necessary. For Whiteside (2013: 339), "The logic of representation itself is part of the problem." Whiteside thus challenges Latour's "reliance on the concept of representation," because it does not provide any substantive ethical standards but only promises to involve "more of today's people, with whatever values and concerns they happen to bring with them" (Whiteside, 2012: 2, 9, original italics). Rather than figuring out how to represent nonhuman nature, Whiteside argues, green theorists should instead design deliberative bodies with"enough authority to oblige represent- ative legislatures to revise or withdraw proposals deemed environmentally unfit" (Whiteside, 2013: 354). Whiteside does not explain what could ensure the democratic legitimacy of such deliberative bodies, nor why they would not also become involved in making claims to represent various constituencies. Indeed, deliberative citizen panels frequently make a variety of representative claims (Brown, 2006). More generally, it seems impossible to avoid entirely claims to speak for nature's interests or to go beyond "the logic of representation" (Whiteside, 2013: 399). Various practices of representation - political, artistic, scientific - are pervasive in human societies. They are also inseparable from democratic politics, and they implicate nonhuman nature in various ways (Brito Vieira, 2009: 251; Brito Vieira and Runciman, 2008: 191).

\section{Constructivist theories of representation and nonhuman agency}

New approaches to representing nonhuman nature can draw on the work of political theorists who over the past two decades have been engaged in a fundamental rethinking of political representation. This rethinking has included both a "representative turn" and a "constructivist turn" in democratic theory (Disch, 2015). First, according to theorists of the representative turn, political representation is not merely a pragmatic concession to the size of modern states, as many participatory democrats have assumed, but rather an inevitable component of nearly all democratic systems (Plotke, 1997; Urbinati, 2006). Except perhaps in very small groups, some people always end up speaking for others. Many democratic theorists have thus criticized the widespread idealization of direct democracy, and they have shown how representation actually improves democracy by opening a gap between public opinion and government decision making, thus increasing possibilities for public deliberation, judgment, and mobilization. These thinkers also treat political representation as a dynamic process, rather than a product of electoral authorization and accountability, and as manifest in a wide range of different kinds of associations, rather than focused in state 
institutions (Mansbridge, 2003; Urbinati and Warren, 2008; Young, 2000).

Second, according to theorists of the constructivist turn, representative claims should not aim for direct correspondence to fixed and preexisting constituencies, but should be understood as partly constituting those same constituencies (Ankersmit, 1996: 45-51; Saward, 2010; Disch, 2012). From this perspective, political representation inevitably contains an aesthetic and performative dimension, such that the process of making representative claims shapes both the representatives and those they represent. This does not necessarily mean that representatives create their constituencies from scratch. Preexisting physical properties, cultural values, and societal interests shape and constrain the range of representative claims that will seem plausible to any given audience (Disch, 2015: 490, 493; Saward, 2006: 192-193; 2010: 75, 80, 192). But these preexisting properties, values, and interests do not determine what counts as representation, nor do they provide an adequate standard for assessing the democratic legitimacy of representative claims.

A useful framework for analyzing the democratic legitimacy of representative claims appears in Saward's The Representative Claim (2010: 36-38). According to Saward, representation involves five elements: a maker of representations puts forward a subject (the representative) that stands for an object (the represented), which is related to a referent and is offered to an audience. For example, the Executive Director of Greenpeace USA (maker) offers Greenpeace USA (subject) to the citizens of the United States (audience) as standing for the survival needs (object) of all the world's people and ecosystems (referent). By distinguishing between the object of representation and its referent, we can see how the represented is constructed in the process of representation. The referent shapes but does not determine the object of representation, and no representative claim captures everything about its referent. Put differently, representation involves making claims not only about what the represented want or need, but also who they are (e.g., hard working people, endangered species).
Whether or not someone counts as a representative, and whether or not their activity amounts to representation, depends on the judgment of the relevant audience. Who belongs to the relevant audience depends on the purpose of representation in a particular case (Rehfeld, 2006). ${ }^{3}$ In the most familiar cases, the audience of a representative claim overlaps with the object of representation (that is, the represented). When a candidate for public office addresses his or her electorate and claims to represent their concerns, the electorate is the audience and its concerns are the object. But in some cases, such as the previous example of Greenpeace, the audience differs either partly or entirely from the proposed object of representation. An official from Greenpeace USA speaks to an audience of US citizens about the needs of the entire planet. People sometimes make a claim to some people that they speak for other people or things. Such claims are legitimate to the extent the audience accepts them as valid. In many cases, such legitimacy may not be democratic, such as when the United Nations accepts the envoy of a nondemocratic country as representing the citizens of that country. The extent to which representative claims are democratically legitimate, according to Saward (2010: 143-160), depends on acceptance by the represented themselves. ${ }^{4}$ An audience might accept a representative claim, thus creating a legitimate representative, but insofar as those who accept the claim are not also the represented, the claim is not democratically legitimate. Democratic legitimacy also depends on the extent to which such acceptance develops in a context of democratic norms, procedures, and conditions (political equality, public deliberation, etc.), however those may be understood in a particular context. As I discuss in more detail later, democratic legitimacy is best examined not primarily in terms of particular representative claims but the political system as a whole.

Of course, most if not all nonhumans lack the capacities necessary for critically assessing human claims to represent them. In Saward's terms, this means that even if nonhumans are part of the intended constituency of a representative claim, they cannot become part of the actual constituency, because they cannot assess and accept the 
claim (Saward, 2010: 150-151). Later in this essay I propose a way of coping with this challenge. Here it is worth noting that just because nonhumans cannot assess representative claims does not mean that they have no rights or do not deserve moral consideration. Nor does it mean that all humans necessarily possess the capacity to assess representative claims. The standard liberal-rationalist conception of an autonomous human subject has been persuasively refuted by feminists, pragmatists, communitarians, and more recently, by scholars of posthumanism, actornetwork theory, new materialism, and related approaches (Gabrielson, 2016; Sayes, 2014). It seems clear that human agency and subjectivity are best understood as social and embodied, as including many nonrational components, and as depending on a wide range of nonhumans. Similarly, agency is probably best understood, not as a uniquely human attribute, but in terms of a spectrum of agentic capacities: insentient entities and most nonhuman animals lack the capacities for critical reflection and norm-responsiveness of most human adults, whereas human children and some nonhuman animals typically exhibit some but not all of those capacities. ${ }^{5}$ Nonetheless, even if we reject an essential boundary between humans and nonhumans, and even if we acknowledge the many ways they constitute each other, we need not conclude that there is never any practical difference between them. In politics and political theory, and especially in theories of democracy, it remains useful to distinguish between humans and nonhumans for certain purposes. Among other things, nonhumans generally lack the capacities for critical reflection and norm-responsiveness that make democracy possible (Krause, 2011). This means that nonhumans require a particular kind of political representation. As I discuss in more detail later, human claims to represent nonhumans cannot be assessed by nonhumans themselves, but they can be assessed by other humans.

This view of agency may seem to conflict with Latour's "flat ontology," which rejects any essential distinctions between humans and nonhumans (Harman, 2009: 12-16; 2014: 18, 39-46; Latour, 1988). Latour (1987, 2005a) argues that all such distinctions be understood in terms of the hybrid networks that create and sustain them. For Latour, especially in an era of climate change, when "the Earth has now taken back all the characteristics of a full-fledged actor," the "competences" of both humans and nonhumans can be determined only after their "performances" (Latour, 2014: 3, 11). Latour has thus often been interpreted as rejecting any distinction between human and nonhumans. ${ }^{6}$ But this is a misunderstanding, produced in part by Latour's own lack of clarity, as well as his shift in emphasis over time. To be sure, from a methodological perspective, Latour insists on agnosticism regarding the distribution of agentic capacities among and between humans and nonhumans. Before embarking upon any particular inquiry, we should never assume "in advance" which actors have which capacities (Latour, 2005a: $16,41,57,160)$. But Latour has also repeatedly acknowledged that agentic capacities become stabilized over time, and so from a theoretical perspective that seeks in part to understand the relations among already constituted entities, Latour's writings support the obvious point that most humans can do many things that most nonhumans cannot (Brown, 2009: 180-183; Latour, 1987; Latour, 2005a: 76).

\section{Latour's Hobbesian view of representation}

In Politics of Nature (2004), Latour proposes an elaborate view of representative democracy as an ongoing process of making and remaking hybrid human-nonhuman collectives. He conceives this process in terms of a bicameral system involving two distinct "powers of representation" that must be exercised through "due process" (Latour, 2004: 108-116, 126). The "first house" in Latour's scheme has the power "to take into account." It detects and discusses new "propositions" that seek admittance to the collective, employing both "perplexity" and "consultation." The "second house" has the power "to arrange in rank order." It engages in "hierarchization" and "institution" to arrange new and existing members of the collective into stabilized forms (Latour, 2004: 109). Latour uses the case of mad cow disease to make his point (Latour, 2004: 111-114). In the early days of the crisis, prions 
were identified as a potential cause of the disease, but their status within the collective was unclear, leading to much controversy over their physical properties and political implications (perplexity and consultation). It became necessary to determine the relative importance of various epistemic claims and policy options (hierarchization), and eventually to establish closure through different forms of codification and naturalization (institution), so that the relevant issues would "no longer be subject to discussion" (Latour, 2004: 114). Most significantly, Latour portrays the two powers of representation as hybrid activities that involve many different kinds of spokespeople, including scientists, politicians, economists, moralists. Each of these kinds of spokespeople has particular skills that they bring to the task of representation. ${ }^{7}$

Latour (2004: 112) says that the work of the first house should not be brought to a close "too soon," and especially not by the imposition of essentialist notions of pre-existing nature. But he also makes clear, as many readers fail to notice, that "there is no need to mix everything up" (Latour, 2004: 112). Once a controversy has run its course, the hybrid assembly will "find itself in the grip of a second power that must of course stabilize the controversy, bring an end to the agitation, and calm the states of alert" (Latour, 2004: 113). This stabilizing of the controversy amounts to establishing clear boundaries between facts and values. Following the closure of the controversy over mad cow disease, for example, "The prion will have become natural: there is now no reason to deprive ourselves of that adjective, which is very convenient for designating, on a routine basis, full-fledged members of the collective" (Latour, 2004: 114, original italics). Latour (2004: 41) thus seeks to avoid the "impossible choice between realism and constructivism." A "fact" is both real and constructed, and indeed, "it is because it is constructed that it is so very real, so autonomous, so independent of our own hands" (Latour, 1999: 275 , original italics). Contrary to the assumption of many readers, Latour does not reject all distinctions between society and nature, values and facts, or humans and nonhumans; instead he historicizes such distinctions.
Despite his parliamentary metaphors, Latour's account of representation is clearly not restricted to familiar state institutions. He sees a need for "techniques of representation in different types of assemblies," and he notes that "parliaments are only a few of the machineries of representation among many others" (Latour, 2005b: 21). Unfortunately, Latour does not discuss how different kinds of assemblies might relate to each other, and he gives no account of their different functions as parts of a political system (Whiteside, 2012: 13). Nonetheless, Latour's account of representation offers a provocative challenge to political scientists who restrict their analyses to electoral politics and state institutions, neglecting the many hybrid forms of sociotechnical representation that shape our common world. But what exactly does Latour mean by "representation"?

In many respects, Latour takes his basic view of representation from Thomas Hobbes. ${ }^{8}$ Hobbes's account of representation is multifaceted and complex, and Latour's writings, as well as my comments here, only touch on a few aspects. Nonetheless, examining the relation between Hobbes and Latour in this regard helps illuminate the potential and limits of Latour's theory of representation. According to Hobbes's (1991: 120) famous account of the social contract in Leviathan, "the multitude" of disconnected individuals in the state of nature agree with each other to give up their natural right to determine for themselves how to protect their own lives, and they authorize one person or assembly to be their representative. They "reduce all their Wills, by plurality of voices, unto one Will: which is as much as to say, to appoint one Man, or Assembly of men, to beare their Person" and to "submit their Wills, every one to his Will, and their Judgements, to his Judgment" (Hobbes, 1991: 120). Most importantly, Hobbes draws on the medieval legal doctrine of corporate personhood to argue that the disconnected members of the "multitude" are not yet a "Person," they do not yet have a collective identity, until they authorize a representative. As Hobbes puts it, "A Multitude of Men, are made One Person, when they are by one man, or one Person, Represented" (Hobbes, 1991: 114; Brito Vieira, 2009: 159-160). Through the social contract, they establish themselves as a "Person," also called a "Commonwealth" 
or "State," with a collective identity. They become "authors" of a sovereign power, which is an "actor" that acts in their name. For Hobbes, that is, the creation of a commonwealth and the authorization of its representative occur simultaneously (Skinner, 2005). There is no people with a collective identity prior to its representation. Moreover, Hobbes's sovereign does not represent the conflicting identities and interests of particular individuals. The sovereign represents an abstraction called a "Commonwealth" or "State," and it represents individual citizens only with regard to the lowest common denominator that unites them, which is their fear of violent death and desire for safety (Brito Vieira, 2009: 181). Hobbes thus sees political representation as a matter of constructing a commonwealth, rather than corresponding to pre-existing public will, opinion, or interest. In this respect, Hobbes's account of representation is similar to recent constructivist theories of both science and politics.

But Hobbes has little sympathy for democracy, and Hobbesian citizens must renounce their right of self-rule. They agree to "own" every action of their representative, as if they had done it themselves, and not to object to their representative's actions on their behalf (Hobbes, 1991: 112). ${ }^{9}$ For Hobbes, representation does not require political expression or advocacy by the represented. Indeed, he sees conflict as a threat to political unity and public safety. The sovereign is obliged by natural law to preserve the commonwealth, but only the sovereign may judge what serves that purpose. In this respect, Hobbes's sovereign representative not only unifies the people but also effectively substitutes itself for them, leaving them no role in the process of representation (Brown, 2009: 118-124; Brito Vieira, 2009: 158-187, 252-253; Brito Vieira and Runciman, 2008: 24-28). ${ }^{10}$

Latour's account of representation has echoed several basic features of Hobbes's theory with surprising consistency ever since an influential early essay with Michel Callon (Callon and Latour, 1981). Callon and Latour draw on Hobbes to provide an account of the processes of translation through which mico-actors (individual humans and nonhumans) transform themselves into macro-actors (institutions). Rather than conceiving micro and macro as two fundamentally different levels of analysis that require different analytical tools, Callon and Latour show how micro-actors become macro-actors by building networks of entities whose interests they translate into a common will. Callon and Latour seek "to show what sociology becomes if we maintain Hobbes's central hypothesis-provided we replace the contract by a general law of translation" (Callon and Latour, 1981: 279). In place of Hobbes's social contract, Callon and Latour present a method for examining how representatives gradually establish themselves through ongoing processes of translation that create alliances and build institutions. For example, Callon and Latour show how efforts to establish a French electric vehicle program involved attempts to unite diverse and conflicting interests under a single representative. But whereas Hobbes (according to Callon and Latour) built the Leviathan "using only contracts and the bodies of ideal, supposedly naked, men" (Callon and Latour, 1981: 294) — that is, using only social elements - Callon and Latour show how those seeking to establish electric vehicle technology built hybrid associations that combined technical and social elements. They had to bring together claims about consumer preferences, for example, with claims about battery technology. Callon and Latour thus present themselves as going beyond Hobbes's account of representation by including both human and nonhuman actors. Latour repeats this argument in later writings (Latour, 1993: 24-27), so it is worth noting that Hobbes actually did not conceive the social contract in purely social, non-materialist terms. Hobbes was a materialist philosopher who understood human beings as "thinking bodies" and the social contract as partly constituted by material phenomena and concerns (Brown, 2009: 107-115; Frost, 2008). The more important point here, however, is that Hobbes provides a key inspiration for Latour's thinking about representation. Moreover, Latour's later writings retain at least four key elements of Hobbes's theory. Both Hobbes and Latour view representation as (1) not corresponding to a pre-existing constituency, but instead (2) constructing, (3) unifying, and (4) substituting for the represented. The first two elements offer conceptual support for democratic 
efforts to represent nonhuman nature, while the second two elements threaten to undermine such efforts.

First, Latour's account of representation echoes Hobbes when he argues that it makes little sense to expect representatives to simply mirror the preexisting views of the people. In Hobbes's time, both defenders of Parliamentary sovereignty and their democratically inclined critics, the Levellers, assumed that Parliament should "stand for" the English people. They agreed that its members should come from all relevant walks of life and its decisions should faithfully correspond to the people's will and opinion. They merely disagreed on whether Parliament was sufficiently representative in this sense. Hobbes argued, in contrast, that no representative body could represent its constituents in this sense, because the people only comes into being through being represented (Skinner, 2005). Similarly, Latour (2004: 152) argues, "A representative who demands that citizens faithfully obey him has no more sense than citizens demanding that politicians faithfully represent them." For Latour (1993: 143), the belief that representatives should directly correspond to their constituents reflects a misplaced distrust of mediation, a "desire for an immediate world, emptied of its mediators."

Second, Latour shares Hobbes's view that processes of representation construct the same constituencies they represent. As noted previously, Latour argues that representatives should not attempt to shut down public debate by appealing to established facts and values, but rather should construct facts and values through "due process." The purpose of representation in both science and politics is to "allow the progressive composition of a common world" (Latour, 2004: 53). Neither scientists nor politicians speak for pre-existing entities, but rather they mobilize and partially constitute the people and things they represent. A people and any other collective identity should be understood as a "provisional unity" that needs to be continually reestablished and maintained (Latour, 2004: 147; Disch, 2008: 92). Moreover, Latour argues that it is not enough to point out that human representations of nature are always mediated. Many social scientists are proud to show that "they are not naive enough to believe in the existence of an 'immediate access' to nature," and yet they still assume that a single universal nature exists beneath or behind all of its social representations (Latour, 2004: 33). For Latour, in contrast, representation involves the creation of new and different natures. Latour thus insists that today's multiculturalism should be complemented by "multinaturalism" (Latour, 2004: 29). Latour here differs from Hobbes, whose materialism assumes a universalist conception of nature as always and everywhere the same. Nonetheless, Latour's constructivist account of representation clearly echoes elements of Hobbes's theory. And Latour's challenge to technocratic claims about nature's objective interests holds considerable promise for the democratic representation of nonhumans. But this potential is undermined by two other elements of Latour's approach.

For over thirty years now, Latour has followed Hobbes in portraying representation as a matter of assembling disparate individuals into a unified whole with a single will. For example, Callon and Latour (1981: 279) argued, "Whenever an actor speaks of 'us,' s/he is translating other actors into a single will, of which s/he becomes spirit and spokesman." Similarly, in his more recent work Latour writes that politicians seek "to obtain the unheard-of metamorphosis of enraged or stifled voices into a single voice" (Latour, 2004: 148). And he has repeatedly portrayed representation as one-half of "the Circle" of politics: "the multitude becomes a unit-representation-before the unit becomes a multitude again-obedience" (Latour, 2003: 150). In Latour's most complete formulation, he writes:

\footnotetext{
Start with a multitude that does not know what it wants but that is suffering and complaining; obtain, by a series of radical transformations, a unified representation of that multitude; then, by a dizzying translation/betrayal, invent a version of its pain and grievances from whole cloth; make it a unified version that will be repeated by certain voices, which in turn ... will bring it back to the multitude in the form of requirements imposed, orders given, laws passed. (Latour, 2013: 341)
}

These requirements, orders, and laws are then translated, transformed, and opposed by "the multitude," leading to new grievances and another 
trip around the never-ending Circle of politics. By tracing the Circle, Latour writes, "we pass time after time from multitude to unity and from unity to multitude" (Latour, 2013: 345; see also Brown, 2009: 172, 178-180, 178-179).

On the one hand, Latour here departs from Hobbes in suggesting that citizens might express grievances about the decisions of their representative. And whereas Hobbes insists that all representative institutions in a commonwealth must be sanctioned by and remain subordinate to the sovereign, which is the "absolute Representative of all the subjects," Latour has a much more open-ended view of an "assembly of assemblies" (Hobbes, 1991: 156; Latour, 2005b: 21). On the other hand, like Hobbes, Latour adopts an undemocratic image of "the multitude" as an inarticulate collection of people that "does not know what it wants," and so representatives must "invent a version" of its desires "from whole cloth" (Latour, 2013: 341). Latour thus suggests that representation does not require ongoing communication between representatives and those they represent. Latour reinforces this view with his expressed skepticism toward public participation in the politics of science and technology (Latour, 2007: 818-819; Harman, 2014: 147). More generally, Latour's account of representation as a matter of the relation between "unity" and "multitude" clearly echoes Hobbes, not only in terminology, but also insofar as both Latour and Hobbes conceive representation in juridical terms as a private legal contract between a single principal (a unified people) and its agent (the representative). Principal-agent views of representation are common in democratic theory, but they are rightly criticized for failing to involve an audience that assesses the relation between principal and agent (Brito Vieira and Runciman, 2008: 69). Moreover, whereas principal-agent theories of democracy portray representation as a matter of authorization and accountability, Latour portrays "the Circle" as a matter of representation and obedience. In this respect, Latour's approach is just as well suited to nondemocratic as democratic forms of representation. A circle of politics that consisted of citizens authorizing their representatives and then holding them accountable would offer at least the beginnings of a demo- cratic conception of representation. But Latour's approach owes more to Hobbes than to advocates of representative democracy.

Nonetheless, we might still ask to what extent democratic politics involves the kind of representation described by Latour. The moment when the "the multitude becomes a unit" (Latour, 2003: 150) might be understood as the outcome of a democratic vote, when diverse voters are momentarily united in their collective authorization of a single law, policy, or candidate. Latour does not discuss voting or any other specific mode of decision making, but his account of representation apparently attempts to capture that brief moment of unity, after the votes are counted and a decision is announced. It could be voters electing a candidate, legislators adopting a law or policy, or lab scientists agreeing on an interpretation of their data. The minority accepts the will of the majority, and temporary unity is produced. Latour does not discuss what he means by unity, but one can imagine different versions. Unity could merely require everyone's grudging acceptance that the decision was legitimate. Or unity could entail personal identification with the decision and the representative people or actions it produces. In either case, the people's sense of unity relies on the assumption that the majority speaks for the whole, that the will of the majority stands for the general will. This "necessary fiction" has become increasingly difficult to sustain in the face of the entrenched conflicts that divide today's pluralist societies (Rosanvallon, 2011: 13). Minorities today often refuse to see themselves in the decisions of the majority, leading to new forms and modes of representation beyond electoral politics. Latour says little about such matters.

Latour's reliance on the juridical aspects of Hobbes's theory of representation also fails to capture many other key aspects of democratic politics. Whereas legal contracts are only binding upon those who agree to them, the decisions of political representatives affect all their constituents, including many who disagree with the decisions. Similarly, we generally expect the winners of democratic elections to represent not only those who voted for them but also those who voted against them, as well as many who did not vote at all. Nonvoters who may require repre- 
sentation include nonhumans, children, people in other countries, and future generations. These diverse constituents have conflicting identities and interests, always subject to change, which means that representatives inevitably betray some constituents while being faithful to others. Indeed, to the extent that individuals are internally conflicted, representatives will be faithful to one aspect of a person's identity, while betraying another aspect. Latour neglects these difficulties that arise with efforts to represent conflicting identities, interests, and forms of knowledge. In such contexts, constituents are never unified for long, and representatives do not betray all their constituents at the same time, in the same way, or to the same extent. Saward makes a similar point with reference to the symbolic frontispiece of Hobbes's Leviathan, which portrays the body of the ruler as composed of the people: "Such symbols may capture realities, but they may also (must also-the symbolism of oneness is necessarily fictional at some level) gloss over realities such as necessary misrepresentation, shifting interests that are not spoken for, the selectivity of portrayals of constituent interests, and so on" (Saward, 2010: 91, original italics). This means that elected officials are "effectively forced to misrepresent us," due to features of the very electoral systems that allow them to represent us in the first place" (Saward, 2010: 92, original italics).

Latour's account obscures this internally differentiated character of democratic representation. To be sure, Latour repeatedly recognizes that politics is disappointing because representatives inevitably betray their constituents (Latour, 2003: $145,151-152)$. But he implicitly retains faithfulness as an aspirational ideal, and he fails to offer a different ideal in its place. "Politicians and scientists all work on the same propositions, the same chains of humans and nonhumans. All endeavor to represent them as faithfully as possible" (Latour, 2004: 148, italics added). Latour suggests that we should stop being disappointed when our representatives betray us, but he says little about how they might represent us in a way that is less disappointing.

Finally, Latour also follows Hobbes in portraying representatives as effectively substituting for the represented. Conceived in this sense, representa- tion amounts to a principal-agent relationship in which principals hire agents to do tasks they cannot do themselves (Brito Vieira and Runciman, 2008: 66-73). Latour's account of representation as substitution appears most starkly in his early discussion of technologies as "delegates" that substitute for humans (Latour, 1992). Latour asks us to think of a door hinge, for example, as the delegate of those who would otherwise have to put a hole in a wall and then repair it every time that someone wanted to leave or enter a building. Similarly, when faced with the problem of an unreliable porter, Latour writes, one has two choices: "either to discipline the people or to substitute for the unreliable humans a delegated nonhuman character whose only function is to open and close the door" (Latour, 1992: 231, original italics). Technologies are delegates of humans, Latour suggests, and as such they substitute for the humans who would otherwise perform the tasks of the technologies. In more general terms, Latour argues elsewhere, "[T]here is not much difference between people and things: they both need someone to talk for them. . . . In each case the spokesperson literally does the talking for who or what cannot talk" (Latour, 1987: 72). What do the spokespeople say? "Only what the things they represent would say if they could talk directly. But the point is that they cannot" (Latour, 1987: 73). When someone's attempt to represent me is successful, Latour writes, "What you are saying is what I would have said if I had spoken" (Latour, 2003: 156). Latour notes that efforts to represent others by substituting for them do not always succeed, and dissenters may raise concerns that a purported spokesperson actually speaks only for him or herself (Latour, 1987: 78). The term spokesperson thus designates "the entire gamut running from complete doubt (I may be a spokesperson, but I am speaking in my own name and not in the name of those I represent) to total confidence (when I speak, it is really those I represent who speak through my mouth)" (Latour, 2004: 64). Latour thus acknowledges that not all efforts to represent others necessarily amount to successful substitution, but he suggests that substitution is the standard to which representatives should aspire. 
Latour's view of representation as substitution not only echoes certain aspects of Hobbes, it also sounds a lot like the typical participatory-democratic critique of representation. Participatory democrats often suggest that because governments inevitably fail to mirror the citizenry - that is, governments fail to substitute for the citizenry by doing what it would have done-representation offers only a second-best, pragmatic alternative to direct democracy (Barber, 1984: 145-146, 245-251). Recent political theories of representation, in contrast, as noted previously, view representative democracy as a distinct governmental form in many ways superior to direct democracy (Plotke, 1997; Urbinati, 2006; Urbinati and Warren, 2008). Latour ignores this body of literature. The result is that direct democracy - with its underlying Hobbesian view of sovereignty as unified collective will-haunts Latour's account of representation. ${ }^{11}$

Moreover, Latour neglects the important differences between representation and substitution. Substitute teachers or football players are usually not directly responsible to those they replace, but rather to their employers or professions. Nor are the actions of substitutes usually binding upon, or otherwise attributed to, those they replace (Pitkin, 1967: 131-133; Whiteside, 2013: 349-350). Similarly, advocating on someone's behalf or serving someone's interests does not by itself amount to representation. Teachers do not usually represent their students, nor doctors their patients, nor plumbers their customers. In each of these cases, some people are serving other people's interests, but their actions are not usually attributed to those they serve. Nor are those being served in any sense present in the relevant activities (Brito Vieira and Runciman, 2008: 67-68). In this respect, many accounts of representing nonhuman nature are better understood as calls for nature advocacy. ${ }^{12}$ Moreover, it seems to belong to the concept of representation - at least to the concept of political representation, as distinct from artistic, scientific, or other forms of representation - that representative claims be contestable. If the represented lack the competence or capacity to object to what is said or done on their behalf, as in many examples of trustee representation, then someone else must be able to object on their behalf. Repre- sentative claims thus require an audience that evaluates the claims (Rehfeld, 2006; Saward, 2010: 48; Brito Vieira and Runciman, 2008: 72-73; Urbinati, 2006: 20; Young, 2000: 126). And while all forms of political representation arguably require an audience, the role of the audience becomes especially important in democratic contexts, when we want to assess whether representative claims are democratically legitimate, as discussed previously. Finally, conceiving representation as substitution mistakenly assumes the need for an identity of rulers and ruled, which is both impossible and undesirable. It is impossible because the citizens of pluralist societies are too diverse to be fully represented by any one representative. It is undesirable because it entails the replacement and passivity of the represented, thus establishing a false opposition between political participation and representation. Representative democracy, in contrast, requires ongoing participation by the represented (Urbinati, 2006; Young, 2000: 124-128). For all these reasons, insofar as Latour portrays representation as substitution, his account offers little guidance for the democratic representation of nonhuman nature.

\section{Representing nature by fiction}

In the preceding section I argued, first, that Latour's account of representation provides valuable resources for understanding how claims to represent nonhuman nature partly constitute the same constituencies they represent. And I argued, second, that Latour's account is less helpful for thinking about how the representation of nonhuman nature can be democratically legitimate. His reliance on a view of representation as substitution, and his assumption that representation aspires to collective unity, offer little guidance for understanding how claims to represent nonhuman nature might be legitimated in pluralist democratic societies. A more promising approach can be found in an aspect of Hobbes's theory that Latour surprisingly neglects: his account of how to represent those who cannot authorize their own representatives.

Authorization involves formal procedures that confer authority to act for some person or thing. A formally authorized representative is in authority, 
whereas a representative whose authority rests on substantive competence is an authority on some topic. Politicians may have very little substantive competence (some names come to mind), and yet still be formally authorized to represent their constituents. Conversely, scientists have substantive expertise, but unless they acquire elective office, they generally lack the formal authority conferred by popular elections. In this respect, formal authority is usually associated with politics, and substantive authority with science. But these two kinds of authority are frequently intertwined. Formal procedures such as peer review and experimental protocols help establish scientific authority, and in this respect substantive expertise relies on formal authorization. And although critics often lament the incompetence of democratic governments, voters are unlikely to repeatedly reelect politicians who lack any substantive competence whatsoever.

Most citizens do not have an opportunity to formally authorize the environmental groups, NGOs, and transnational institutions that claim to represent their presumed interest in protecting nature. And nonhumans cannot directly authorize those claiming to represent them. O'Neill (2001: 494; 2003: 270) concludes that authorization cannot play any role in the representation of nonhumans. But another look at Hobbes suggests a different answer.

As noted previously, Hobbes argues that the sovereign does not represent individual citizens in their particularity but the abstract entity of the state (Brown, 2009: 128-132). And because the state is an abstract entity, it cannot authorize its own representative. The sovereign is thus author- ized by a multitude of individuals through the social contract, and the sovereign then represents the state. In Hobbes's terminology, this means that state is not represented "truly" but rather "by fiction."Those who represent "truly" are authorized by those they represent. Those who represent "by fiction" are authorized by someone else (Hobbes, 1991: 111; Brito Vieira, 2009: 147-148, 172). Figure 1 shows Hobbes's theory of representation by fiction in the case of the sovereign authorized by the multitude to represent the state.

As Hobbes (1991: 113) goes on to explain, "There are few things, that are uncapable of being represented by Fiction." As examples of entities that can be represented by fiction, Hobbes mentions "a Church, an Hospital, a Bridge," as well as "Children, Fooles, and Mad-men that have no use of reason" and "the Gods of the Heathen." These people and things cannot authorize their own representatives, but "those that are the Owners, or Governours of those things," or have "Dominion" over them, may authorize representatives for them (Hobbes, 1991: 113). The owner of a church, hospital, or bridge, for example, might appoint someone to "procure their maintenance," and that person would represent those things by authority of the owner. Similarly, with regard to children and others who lack reason, "he that hath right of governing them, may give Authority to the Guardian" (Hobbes, 1991: 113)..$^{13}$ The state differs from Hobbes's other examples of representation by fiction, because the state is created from scratch by the authorization of its representative, and it continues to exist only through representation. This means the state cannot have any interests independently of its representation

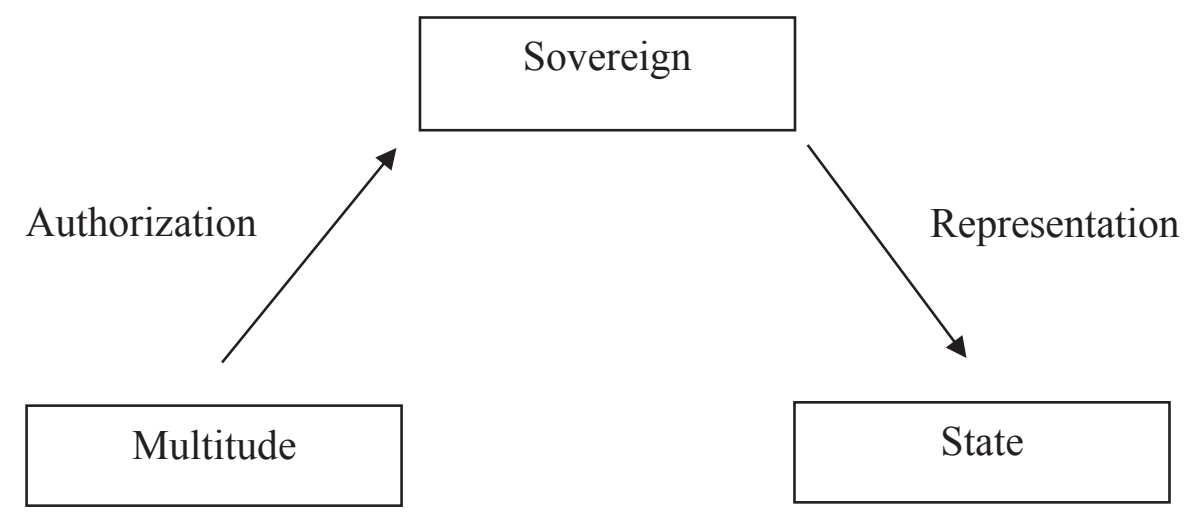

Figure 1. Hobbes's theory of representation by fiction (adapted from Runciman, 2009: 21). 
by the sovereign. Citizens thus have no basis to contest how the sovereign represents them in their collective identity as a state (Hobbes 1991: 124). But Children, fools, madmen, and inanimate objects exist and may have interests prior to and independently of being represented, and those interests might become matters of dispute. Actions of a legal guardian on a child's behalf, for example, might be challenged by another representative of the child appointed by a court (Brito Vieira, 2009: 157-158). ${ }^{14}$

Hobbes's discussion suggests the need for an audience of representation. Not only can a bridge not authorize its own representative, but it also cannot recognize its representative as such, and so others must recognize the bridge's representative. In this respect, Hobbes sees representation by fiction as an ongoing process in which citizen witnesses, as the audience of representation, imaginatively construct a relationship between representatives and those they represent (Runciman, 2000; Skinner, 1999; Brito Vieira, 2009: 143-144, 248-253). Slightly revising Saward's (2010) framework, we might say that representation by fiction involves an owner who authorizes an actor to stand for a person by fiction, which is related to a referent (the entity that cannot authorize its own representative), before an audience.

Hobbes's notion of representation by fiction offers a new way to think about representing nature's interests. ${ }^{15}$ Like the children, gods, and inanimate things mentioned by Hobbes, nonhuman entities and processes cannot authorize those who claim to represent them. But those who want to represent a particular nonhuman animal, species, habitat, or ecosystem, or even the entire planet, might do so "by fiction." The fiction is that the nonhumans can authorize and take responsibility for their representatives. Following Hobbes, representatives of this sort need to be authorized by the private owners or public authorities with dominion or legal rights over the nonhumans in question. For Hobbes, the single absolute sovereign has dominion, but in a context of popular sovereignty we might say it is the entire citizenry. The authority to represent nonhuman interests, from this perspective, rests not primarily on claims to moral or technical knowledge, but on formal authorization and its recognition by an audience. And whereas Hobbes aims to reduce or eliminate conflict over the standards of effective representation, in a democratic context we might depart from Hobbes and promote lively debate among competing claims to represent nonhumans. Most nonhumans lack the capacity to assess how they are being represented, but such assessment can be undertaken by the audience of representation.

This approach does not meet the standard of democratic legitimacy outlined previously, because only the audience and not the represented themselves can assess a claim to represent nonhuman nature. But this poses less of a problem if we view representative democracy as comprised of a diverse ecology of institutions, and democratic legitimacy as a potential attribute of the entire political system rather than particular representative claims (Brown, 2009: 204-206; Parkinson and Mansbridge, 2012; Rosanvallon, 2011; Saward, 2010: 163-168). Modern democracies depend on many practices and institutions that are not themselves entirely democratic. Expert advisory committees are usually not directly accountable to ordinary citizens, but if they provide the expertise that citizens require, they can improve the fairness and effectiveness of the entire political system. Citizen protest movements and advocacy groups are often highly partisan and non-deliberative, but if they call attention to excluded issues and constituencies, they can improve the deliberative quality and representativeness of other institutions and the system as a whole. The democratic legitimacy of such practices and institutions is indirect. It depends on their fulfilling a particular role within a complex political system. From this perspective, democratic legitimacy does not require that nonhumans themselves assess representative claims on their behalf. It requires only that the human audience of such claims accept them as valuable contributions to an ongoing process of representative democracy.

Representing nature in this sense is a bit like trustees representing a charitable trust or directors representing a corporation (Brito Vieira and Runciman, 2008: 96-103). Since a corporation, as an abstract entity, cannot authorize its own representatives, they need to be authorized by a third 
party. The corporation's owners or shareholders thus authorize a board of directors to represent not only the owners or shareholders but also the corporation itself. Unlike the epistemic trustees discussed earlier, whose authority rests on claims to moral or scientific expertise, the authority of Hobbesian trustees depends on formal authorization and the recognition of such authorization by the relevant audience. The relevant audience is not nonhumans themselves, but the human citizens to whom nature's trustees address their representative claims. Figure 2 suggests how democratic publics might both authorize trustees to represent nonhumans and then seek to hold them accountable.

This Hobbesian perspective on representing nonhuman nature does not depend on answering vexing questions about nonhuman agency and interests - or more precisely, it transforms such questions into political rather than scientific or philosophical problems. For Hobbes, representation does not require the discernment of genuine interests or identities but only their fictive attribution. ${ }^{16}$ This does not mean that Hobbes is a radical constructivist who sees no material constraints on successful representation. Hobbes makes clear that the authority of representatives extends only "so far-forth as is in their Commission, but no farther" (Hobbes, 1991: 112). The sovereign who represents the commonwealth is commissioned to secure the requirements of civil peace, which "requires great knowledge" in many different areas, and hence the advice of various counselors (Hobbes, 1991: 180). If the sovereign fails to secure civil peace, the subjects are no longer obligated to obey (Hobbes, 1991: 153). And anyone who violates the laws of nature will suffer "Naturall Punishments," which are the inevitable negative consequences of intemperance, rashness, injustice, pride, and other imprudent attributes and actions (Hobbes, 1991: 253-254). Similarly, when Hobbes says that a guardian who represents by fiction will "procure the maintenance" of a hospital or bridge, Hobbes suggests that such maintenance must fulfill certain preexisting requirements (Hobbes 1991: 113). But representatives, not their counselors or those they represent, have final authority to decide on the means of fulfilling those requirements. A Hobbesian approach thus involves acting as if nonhumans have specific interests and support certain policies, even if we cannot agree on whether they actually have interests or what they are (Smith, 2012: 108). If an official of the U.S. Environmental Protection Agency, who is publicly authorized to represent nonhuman nature, says that polar bears want their habitat protected, and the official's audience accepts the claim, the official has become the legitimate representative of the polar bears. Like a novel or play, Hobbesian representation by fiction does not require that we entirely forget the representation is a fiction, as long as we simultaneously allow ourselves to think and act as if it were not. ${ }^{17}$

Hobbes's theory of representation by fiction suggests that some advocates for nonhuman nature might complement the epistemic justifications of their representative claims with claims

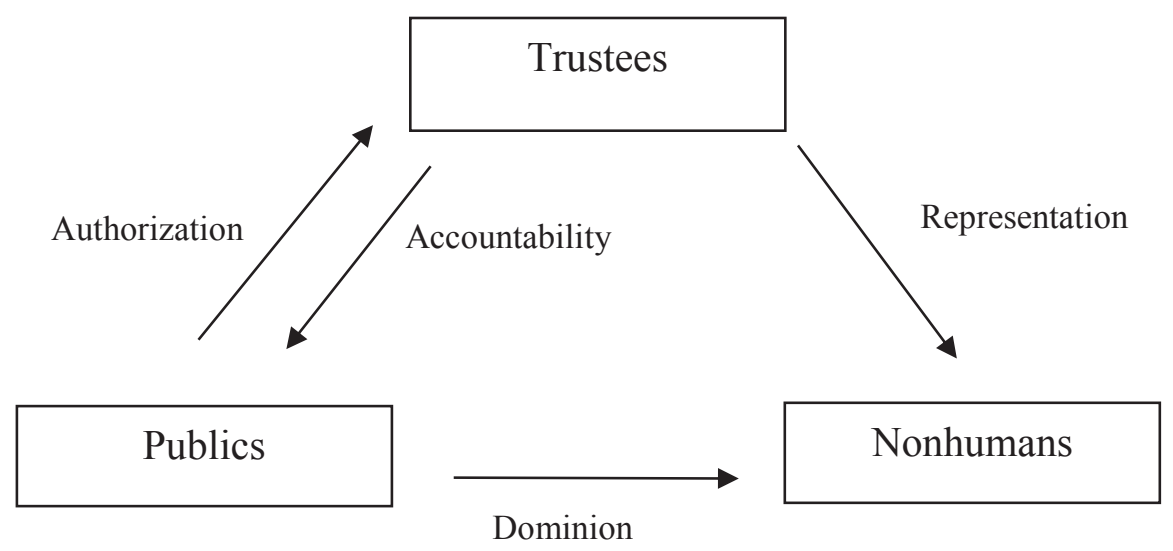

Figure 2. Democratic representation of nonhumans by fiction 
based on formal authorization. Governmental environmental protection agencies, for example, might be seen as formally authorized by the electorate to represent nonhuman interests. Environmental organizations, animals rights groups, and green political parties might be understood as formally authorized by their members or voters to speak for nonhumans. The Dutch Party for the Animals (PvdD) holds numerous elected seats at all levels of government. In Los Angeles many Neighborhood Councils appoint a Director of Animal Welfare (Smith, 2012: 109-112). ${ }^{18}$ To be sure, conceiving such organizations as formally authorized representatives of nonhuman nature will not guarantee protection of nonhuman interests or eliminate political conflict. Members of the relevant audience might dispute the representative's actions, and there may be additional disagreements over who belongs to the relevant audience. For Hobbes, any such disagreements must be quickly and definitively resolved by the sovereign, and the sovereign must be either a small assembly or a single individual. In today's pluralist democracies, in contrast, political legitimacy depends on broad public debate that includes diverse and conflicting efforts to speak for nonhuman nature. But a Hobbesian approach may help prevent such debate from becoming preoccupied with intractable philosophical or scientific disagreements. It may be especially helpful when the time comes for ending debate and making provisional yet authoritative decisions.

\section{Conclusion}

Taken by themselves, neither Hobbes nor Latour offers a theory of representation fully amenable to representing nonhuman nature in democratic societies. Useful resources for developing such a theory appear in their shared view of representation as a process that does not directly correspond to preexisting attributes but partly constitutes what it represents. But Latour's reliance on the juridical aspects of Hobbes's theory, especially his view of representation as a matter of unifying and replacing the represented, undermines the democratic potential of his account of representation. A more promising approach appears in Hobbes's theory of representation by fiction.

Representation by fiction is clearly not the only way to represent nonhuman nature. Different institutions support different types of representative claims, and vibrant democracies require an ecology of different kinds of representation. Saward (2006: 197) thus argues for "institutionalising multiple modes of representing a range of shifting human and nonhuman interests" such that we can "test openly in argument varied representations of nature." From this perspective, the representation of nonhuman nature is best understood as distributed across diverse institutions with diverse mandates, constituencies, and capacities. This means that whether nature is well or poorly represented depends not on any single representative body, but on a global ecology of representative institutions. Some institutions might rely primarily on epistemic claims to represent nonhuman nature. But given the frequent failure of epistemic claims to acquire public support, it seems prudent to view some individuals and institutions in Hobbesian terms as publicly authorized to represent nonhuman nature by fiction.

\section{Acknowledgements}

For helpful feedback on earlier versions of this article, many thanks to Mónica Brito Vieira, Lisa Disch, Matthijs Kouw, John Meyer, Monicka Patterson-Tutschka, Arthur Petersen, and two anonymous reviewers. They are of course not responsible for any shortcomings. 


\section{References}

Ankersmit FR (1996) Aesthetic Politics: Political Philosophy Beyond Fact and Value. Stanford, CA: Stanford University Press.

Barber B (1984) Strong Democracy: Participatory Politics for a New Age. Berkeley and Los Angeles: University of California Press.

Brito Vieira M (2009) The Elements of Representation in Hobbes: Aesthetics, Theatre, Law, and Theology in the Construction of Hobbes's Theory of the State. Leiden and Boston: Brill.

Brito Vieira M and Runciman D (2008) Representation. Cambridge: Polity Press.

Brown MB (2006) Citizen Panels and the Concept of Representation. Journal of Political Philosophy 14(2): 203-225.

Brown MB (2009) Science in Democracy: Expertise, Institutions, and Representation. Cambridge, MA: MIT Press.

Callon M and Latour B (1981) Unscrewing the Big Leviathan: How Actors Macro-Structure Reality and How Sociologists Help Them to Do So. In: Knorr-Cetina K (ed) Advances in Social Theory: Toward an Integration of Micro-and Macro-sociologies. London: Routledge and Kegan Paul, pp. 277-303.

Carbone L (2004) What Animals Want: Expertise and Advocacy in Laboratory Animal Welfare Policy. New York: Oxford University Press.

Disch L (2008) Representation as 'Spokespersonship': Bruno Latour's Political Theory. Parallax 14(3): 88-100.

Disch L (2012) Democratic Representation and the Constituency Paradox. Perspectives on Politics 10(3): 599-616.

Disch L (2015) The 'Constructivist Turn' in Democratic Representation: A Normative Dead End? Constellations 22(4): 487-499.

Disch L (2016) Ecological Democracy and the Co-Participation of Things. In: Gabrielson T, Hall C, Meyer J and Schlosberg D (eds) The Oxford Handbook of Environmental Political Theory. New York: Oxford University Press, pp. 624-639.

Dobson A (1996) Representative Democracy and the Environment. In: Lafferty W M and Meadowcroft J (eds) Democracy and the Environment: Problems and Prospects. Cheltenham: Edward Elgar, pp. 124-139.

Dobson A (2010) Democracy and Nature: Speaking and Listening. Political Studies 58 (4): 752-768.

Donaldson S and Kymlicka W (2011) Zoopolis: A Political Theory of Animal Rights. New York: Oxford University Press.

Donaldson S and Kymlicka W (2014) Animals and the Frontiers of Citizenship. Oxford Journal of Legal Studies 34(2): 201-219.

Dryzek JS (2000) Deliberative Democracy and Beyond: Liberals, Critics, Contestations. Oxford and New York: Oxford University Press.

Eckersley R (2000) Deliberative Democracy, Ecological Representation and Risk: Towards a Democracy of the Affected. In: Saward M (ed) Democratic Innovation: Deliberation, Representation and Association. London: Routledge, pp. 117-132.

Eckersley R (2004) The Green State: Rethinking Democracy and Sovereignty. Cambridge, MA: MIT Press.

Eckersley R (2011) Representing Nature. In: Alonso S, Keane J and Merkel W (eds) The Future of Representative Democracy. Cambridge: Cambridge University Press, pp. 236-257.

Frost S (2008) Lessons from a Materialist Thinker: Hobbesian Reflections on Ethics and Politics. Stanford, CA: Stanford University Press. 
Gabrielson T (2016) Bodies, Environment, Agency. In: Gabrielson T, Hall C, Meyer J and Schlosberg D (eds) The Oxford Handbook of Environmental Political Theory. New York: Oxford University Press, pp. 399-412.

Goodin RE (1996) Enfranchising the Earth, and its Alternatives. Political Studies 44 (5): 835-849.

Harman G (2009) Prince of Networks: Bruno Latour and Metaphysics. Melbourne: re.press.

Harman G (2014) Bruno Latour: Reassembling the Political. London: Pluto Press.

Hobbes T (1991) Leviathan. Revised student edition edited by Richard Tuck. Cambridge: Cambridge University Press.

Jasanoff S, Markle GE, Petersen JC and Pinch T (eds) (1995) Handbook of Science and Technology Studies. Thousand Oaks, CA: Sage Publications.

Krause S (2011) Bodies in Action: Corporeal Agency and Democratic Politics. Political Theory 39(3): $299-324$.

Latour B (1987) Science in Action: How to Follow Scientists and Engineers through Society. Cambridge, MA: Harvard University Press.

Latour B (1988) The Pasteurization of France (trans. A. Sheridan and J. Law). Cambridge, MA: Harvard University Press.

Latour B (1992) Where Are the Missing Masses? The Sociology of a Few Mundane Artifacts. In: Bijker WE and Law J (eds) Shaping Technology/Building Society: Studies in Sociotechnical Change. Cambridge, MA: MIT Press, pp. 225-258.

Latour B (1993) We Have Never Been Modern (trans. C Porter). Cambridge, MA: Harvard University Press.

Latour B (1999) Pandora's Hope: Essays on the Reality of Science Studies. Cambridge, MA: Harvard University Press.

Latour B (2002) War of the Worlds: What about Peace? Chicago, IL: Prickly Paradigm Press.

Latour B (2003) What if We Talked Politics a Little? Contemporary Political Theory 2(2): 143-164.

Latour B (2004) Politics of Nature: How to Bring the Sciences into Democracy (trans. C Porter). Cambridge, MA: Harvard University Press.

Latour B (2005a) Reassembling the Social: An Introduction to Actor-Network-Theory. Oxford and New York: Oxford University Press.

Latour, B (2005b) From Realpolitik to Dingpolitik, or How to Make Things Public. In: Latour B and Weibel P (eds) Making Things Public: Atmospheres of Democracy. Cambridge: MIT Press, pp. 14-41.

Latour B (2013) An Inquiry into Modes of Existence (trans. C Porter). Cambridge, MA: Harvard University Press.

Latour B (2014) Agency at the Time of the Anthropocene. New Literary History 45(1): 1-18.

Mansbridge JJ (2003) Rethinking Representation. American Political Science Review 97 (4): 515-528.

Marres N (2012) Material Participation: Technology, the Environment and Everyday Publics. New York: Palgrave Macmillan.

Nordhaus T and Shellenberger M (2007) Break Through: Why We Can't Leave Saving the Planet to Environmentalists. Boston and New York: Houghton Mifflin Harcourt.

O'Neill J (2001) Representing People, Representing Nature, Representing the World. Environment and Planning C: Government and Policy 19(4): 483-500.

O'Neill J (2006) Who Speaks for Nature? In: Haila Y and Dyke C (eds) How Nature Speaks: The Dynamics of the Human Ecological Condition. Durham, NC: Duke University Press, pp. 261-277.

Parkinson J and Mansbridge J (eds) (2012) Deliberative Systems. Cambridge: Cambridge University Press. Pitkin HF (1967) The Concept of Representation. Berkeley and Los Angeles: University of California Press. 
Plotke D (1997) Representation Is Democracy. Constellations 4(1): 19-34.

Rehfeld A (2006) Towards a General Theory of Political Representation. Journal of Politics 68(1): 1-21.

Rosanvallon P (2011) Democratic Legitimacy: Impartiality, Reflexivity, Proximity (trans. A. Goldhammer). Princeton, NJ: Princeton University Press.

Runciman D (2000) What Kind of Person Is Hobbes's State? A Reply to Skinner. Journal of Political Philosophy 8(2): 268-278.

Runciman D (2009). Hobbes's Theory of Representation: Anti-Democratic or Proto-Democratic? In: Shapiro I, Stokes SC, Wood EJ and Kirshner AS (eds) Political Representation. Cambridge: Cambridge University Press, pp. 15-34.

Sarewitz D (2004) How Science Makes Environmental Controversies Worse. Environmental Science and Policy 7: 385-403.

Saward M (2006) Representation. In: Dobson A and Eckersley R (eds) Political Theory and the Ecological Challenge. Cambridge: Cambridge University Press, pp. 183-199.

Saward M (2010) The Representative Claim. Oxford: Oxford University Press.

Sayes E (2014) Actor-Network Theory and Methodology: Just What Does It Mean to Say That Nonhumans Have Agency? Social Studies of Science 44(1): 134-149.

Schlosberg D (2007) Defining Environmental Justice: Theories, Movements, and Nature. New York: Oxford University Press.

Shapin S and Schaffer S (1985) Leviathan and the Air-Pump: Hobbes, Boyle, and the Experimental Life. Princeton, NJ: Princeton University Press.

Skinner Q (1999) Hobbes and the Purely Artificial Person of the State. Journal of Political Philosophy 7(1): 1-29.

Skinner Q (2005) Hobbes on Representation. European Journal of Philosophy 13(2): 155-184.

Smith KK (2012) Governing Animals: Animal Welfare and the Liberal State. New York: Oxford University Press.

Urbinati N (2006) Representative Democracy: Principles and Genealogy. Chicago: University of Chicago Press.

Urbinati N and Warren ME (2008) The Concept of Representation in Contemporary Democratic Theory. Annual Review of Political Science 11: 387-412.

Whiteside KH (2012) A Representative Politics of Nature? Bruno Latour on Collectives and Constitutions. Contemporary Political Theory 12(3): 185-2005.

Whiteside KH (2013) The Impasses of Ecological Representation. Environmental Values 22: 339-358.

Wise S (2010) Legal Personhood and the Nonhuman Rights Project. Animal Law 17(1): 1-12.

Young IM (2000) Inclusion and Democracy. New York: Oxford University Press. 


\section{Notes}

1 Latour's most prominent departure from Hobbes occurs in his rejection of Shapin and Schaffer's claim that "Hobbes was right" to assert that scientific knowledge is determined by society (Shapin and Schaffer, 1985: 344). In response Latour asserts, "No, Hobbes was wrong," because both humans and nonhumans play a role in the construction of scientific facts (Latour, 1993: 26). Despite their disagreement over whether Hobbes was "right," these portrayals share a mistaken view of Hobbes as a radical social constructivist who saw no causal role for material things in either science or politics (see Brown, 2009: 107-115). I discuss this issue in more detail later.

2 Smith (2012: 99-125) is an important exception and makes some of the same points as this article.

3 Rehfeld (2006: 15-17) suggests that it is relatively easy to identify the relevant audience and whether it accepts someone as a representative, and thus whether representation "in fact" exists. Normative conflicts, he suggests, should focus on the legitimacy of the representatives rather than who they are. Saward (2010: 27-28, 55-56), in contrast, argues that the intended audience and/or constituency of a representative claim may differ from the actual audience and/or constituency. Moreover, audiences and constituencies emerge and change through the process of representation, and so both the identity and legitimacy of representatives are often a matter of ongoing contestation.

4 More precisely, the democratic legitimacy of a representative claim depends on its acceptance by the "appropriate constituency," which includes both the actual and intended objects of a representative claim. That is, it includes all the people who accept or assert that a claim represents them, regardless of whether or not the person making the claim intended to represent them (Saward, 2010: 148-149).

5 Donaldson and Kymlicka $(2011,2014)$ rightly argue that domesticated animals exhibit many characteristics of membership in human communities, including responsiveness to social norms, even if they cannot reflect on such norms.

6 Harman (2014: 81-82) argues that "the early Latour" asks us to "dissolve" modernist dichotomies between nature and culture, while Latour's identification of distinct "modes of existence," including "science" and "politics," each with its own criteria of felicity, belongs to "the late Latour". Latour has certainly shifted his emphasis over time, but Harman overstates his argument. At least as early as Science in Action (1987), Latour argued that the closure of controversies results in stabilized boundaries between subjects and objects, nature and culture, facts and values. Indeed, Harman (2014: 29) claims rather extravagantly that "since the work of the late Latour began in secret in the late 1980s, it was actually simultaneous with the early and middle periods." Harman goes on to say that the "old and new voices of Latour may co-exist for some time to come," but this "presents no problem, since they are perfectly compatible" (Harman, 2014: 81). It seems that these two "voices" are better understood as component parts of a single approach that does not entirely reject modernist boundaries but provides a methodology for showing how they become established and stabilized over time.

7 Politicians and scientists both represent the same world, but they do so in different ways. The notion of faithful representation means something different for each: "scientists have to maintain the distance between the propositions that they load into language and what they say about them, so that these two things will not be confused." In contrast, politicians need to "confuse them by continually modifying the definition of the subjects who say 'we are, we want.'The former are guardians of the 'them, the latter masters of the 'us'"' (Latour, 2004: 148).

8 Portions of this section draw on Brown (2009: 108-110, 172-180)

9 Even though Hobbes rejects any kind of citizen participation that would challenge the sovereign, he suggests that citizens must participate in upholding a public image of themselves as a unified people. Hobbes's theory of representation thus goes beyond the moment of sovereign authorization (Pitkin, 1967), and it suggests the need of an ongoing process for maintaining sovereign authority (Brito Vieira, 2009; Runciman, 2009). 
10 Ankersmit (1996: 45-46) uses the term "substitution" differently than I do here. He associates the notion of representation as substitution with aesthetic or constructivist theories of representation, which he contrast with mimetic theories that require an identity of representative and represented. In contrast, I follow Urbinati (2006: 18-25, 104) and Young (2000: 126) in characterizing mimetic and juridical theories as based on the "substitution" or replacement of the represented by the representative. Mimetic and juridical theories differ in their criteria for establishing someone as a representative (resemblance and authorization, respectively), but they both remove the represented from the process of representation.

11 As Brito Vieira (2009: 241-242) writes, "Hobbes's theory of political representation reproduces the psychologically oppressive identity logic of direct democracy. Hobbes's theory generates an absolute coincidence between people and sovereign, represented and representative, as for him 'the people' does not exist except as united in one sovereign representative whose will must count as the will of everyone." She also explains, partly disputing the account in Ankersmit (1996: 29), that Hobbes's theory of representation goes beyond this logic of identity, because he asks citizens to adopt a double perspective: with respect to their shared identity, citizens must see themselves in the state; and with respect to their particular identities, they must accept their separation from the state and its sovereign representative whose actions they may not dispute (Brito Vieira, 2009). In this respect, Hobbes's theory of representation contains elements of both identity and difference, mimesis and poiesis. Nonetheless, the key point here is that Hobbes sees the relation between the sovereign and the state as a relation of identity, like that between the people and the government in theories of direct democracy.

12 Eckersley (2011) uses the phrases "nature advocacy" and "representing nature" synonymously, but the first phrase fits her account much better than the second. She argues only that environmentalists should be advocates for the intrinsic value of nonhuman nature, not that such advocacy should involve the figurative presence of nonhumans or be attributed to them. On the difference between advocacy and representation, see Smith (2012: 116-117).

13 "In handing over authority to procure the thing's maintenance, the owner or governor makes manifest his intention to treat the thing as something enjoying an existence and interests of its own, which deserve special protection, in so far as they may stand over and above the transient interests of its several owners or governors. Once the inanimate thing starts being personated, it gains animation, allowing us to speak of the thing's will, interests and actions for the first time.... therein lies the fiction" (Brito Vieira, 2009: 154).

14 The state also differs from Hobbes's other examples of representation by fiction, because the latter all require the existence of a state that can establish who has dominion.

15 This section expands on Brown (2009: 124-132). See also Brito Vieira and Runciman (2008: 101, 189-192)

16 Hobbes's notion that we fictively attribute interests to nonhumans has affinities with Marres (2012: 1-2, 104-105, 111-112), who approaches nonhuman agency not as a general philosophical question but as a performative accomplishment of particular settings that invest things with various capacities. But Marres says little about the specific relations of political authority and representation among those who invest nonhumans with agency (see also Disch, 2016: 632).

17 In the case of a stage play, a playwright or theater company authorizes an actor to represent a fictional character on the stage. The playwright or theater company, not the character, is responsible for what the actor says in the character's name (Brito Vieira 2009: 155).

18 Efforts to attribute legal personhood to animals also rely in part on formally authorizing humans to represent nonhumans (Smith 2012: 118-123; Wise 2010). But such efforts offer legal rather than political representation. They seek to ensure the enforcement of existing laws to protect the welfare and dignity of individual animals, rather than to create new policies that can be attributed to collective nonhuman interests. The Swiss canton of Zurich, for example, once employed an animal advocate, authorized by law to represent the interests of animals in court (Donaldson and Kymlicka 2011: 208). See also the website of the Nonhuman Right Project: https://www.nonhumanrightsproject.org 